\title{
ABOUT THE PROBLEM OF RELIABILITY IN SPORTS GAMES
}

\section{Beknazarov A.R.}

Lecturer, Department Theory And Methodology Of Physical Culture, Sports, Institute For Retraining And Advanced Training Of Specialists In Physical Culture And Sports, Tashkent, Uzbekistan

\section{ABSTRACT}

In this article highlighted about that improving the reliability of playing actions in competitions is one of the most important problems in the training of highly qualified athletes. Many authors consider that the reliability criterion in a sport activity is the accuracy of the motor action fulfillment. It is expected that constant monitoring of the functional state, physical qualities and technical and tactical training of athletes will allow achieving effective results in the course of sports competitions.

KEYWORDS: - Technical and tactical actions of football players, pedagogical observations on assessing the level of reliability of performing technical and tactical actions. TTD of football players.

\section{INTRODUCTION}

Improving the reliability of playing actions in competitions is one of the most important problems in the training of highly qualified athletes. Many authors believe that the reliability criterion in sports activity is the accuracy of motor action fulfillment (authors: M.A. Godik, 2010, V.Zaletskiy, 2014).

A number of factors, which can have both positive and negative effects, also affect the reliability of motor activity fulfillment. Playing sports, in particular, football, is characterized by a complex nature of competitive activity, in conditions of variability in the presence of a large number of technical and tactical actions, subject to their optimal correlation with the tasks of both partners and rivals.

The functioning of sports activity in these conditions is characterized by an optimal level of preparedness, which is within the framework of the abilities, limited by the possibilities of human activity.

The more an athlete realizes his technical and tactical readiness in difficult conditions of playing tension, the higher the reliability.

In football, the reliability of performing technical and tactical actions with the ball is considered as the probability of error-free performance of these actions during the game.

Theoretical prerequisites and analysis of literary sources made it possible to identify three main factors affecting the reliability of performing technical and tactical actions with the ball (T.A. Litsenchuk, 2006, M.A. Godik, 2010, Sh.I. Miev, 2016)

- the presence of combat sports 
CURRENT RESEARCH JOURNAL OF PEDAGOGICS 2(8): 77-79, August

2021 DOI: https://doi.org/10.37547/pedagogics-crjp-02-08-17

ISSN 2767-3278

(C)2021 Master Journals

\section{Crossref do) 81 Google}

Accepted 26 th August, 2021 \& Published 31 th August, 2021

- lack of time and space

- the severity of the game situation.

The reliability of game actions is assessed on an equal to variable scale of points from 1 to \pm 5 by recording game actions on video of technical and tactical actions, in attack and defense. The presence of these factors determined the level of gaming tension.

In the practice of football, there are three types of game tension:

- simple

-complicated

- complex

Simple is the fulfillment of a motor action in a simple situation that does not involve combat sports, is not limited by the lack of time and space.

Exact performance plus 1 point, imprecise minus 5 points.

Complicated - performance of technical and tactical actions in combat sports, lack of time and space, but in the absence of an acute game situation. Exact performance plus 3 points, imprecise minus 3 points.

Complex - the fulfillment of a motor action in a difficult game situation in the presence of combat sports, lack of time and space.

Exact performance - plus 5 points, inaccurate performance - minus 1 point.

After that, the sums of positive and negative points are summed up.

The quantitative assessment of reliability is calculated according to the formula "reliability factor"

$$
R F=\frac{\sum n-\sum m}{\sum n}=
$$

- the sum of all points

- the sum of negative points

RF- Reliability factor

The reliability factor can be calculated for attacking and defensive technical-tactical actions. It can be calculated separately for the player and for the team as a whole.

It is important to note that the high level of reliability in performing game actions is an indicator of the effectiveness of the players' playing activity. Pedagogical observations to assess the reliability coefficient of technical and tactical actions were carried out in the Pakhtakor football team in the super league of the championship of Uzbekistan in 2020 (table-1). From table- 1 it can be seen that the reliability indicator ranges from 0.753 to 0.844 , the average indicator for 9 games is from 0.804 in offensive actions, and from 0.707 .

The indicators of the reliability of performing game actions at home in the attack are from 0.753 to 0.844 . In protection from 0.573 to 0.784 . It should be noted that there is a relationship between the indicators of the reliability of the performance of game actions and the effectiveness of the team, which indicates that a high level of reliability of the performance of game actions is one of the indicators of the game activity of the activity of football players.

Pedagogical observations on the assessment of the coefficient of reliability of the performance of technical and tactical actions were carried out in the football team "Pakhtakor" in the super league of the championship of Uzbekistan in 2020. (Table-1) [5]. 
CURRENT RESEARCH JOURNAL OF PEDAGOGICS 2(8): 77-79, August

2021 DOI: https://doi.org/10.37547/pedagogics-crjp-02-08-17

ISSN 2767-3278

(C)2021 Master Journals

Crossref dof 81 Google

Accepted 26 ${ }^{\text {th }}$ August, 2021 \& Published 31 th August, 2021

The results of pedagogical observations of the TTD of football players f.c. "Pakhtakor"

\begin{tabular}{|c|c|c|c|c|c|c|c|c|c|}
\hline \multirow{2}{*}{\begin{tabular}{|c} 
Indic \\
ators \\
TTD
\end{tabular}} & \multicolumn{9}{|c|}{ commands } \\
\hline & $\begin{array}{l}\mathrm{N} \\
\text { ovbah } \\
\text { or }\end{array}$ & $\begin{array}{l}\text { B } \\
\text { ukhor } \\
\text { o }\end{array}$ & $\begin{array}{l}\text { Me } \\
\text { tallurgi } \\
\text { st }\end{array}$ & $\begin{array}{l}\quad \text { S } \\
\text { uudiyo } \\
\text { na }\end{array}$ & $\begin{array}{l}\text { B } \\
\text { unyod } \\
\text { kor }\end{array}$ & $\begin{array}{r}\mathrm{Ki} \\
\text { zilkum }\end{array}$ & $\begin{array}{l}\text { S } \\
\text { urkho } \\
n\end{array}$ & $\begin{array}{l}\mathrm{M} \\
\text { ashal }\end{array}$ & $\begin{array}{l}\text { A } \\
\text { GMK }\end{array}$ \\
\hline date & $\begin{array}{l}27 \\
02 . \\
2020\end{array}$ & $\begin{array}{r}8 \\
.03 .20 \\
20\end{array}$ & $\begin{array}{r}14 \\
03.202 \\
0\end{array}$ & $\begin{array}{r}1 \\
4.06 .2 \\
020\end{array}$ & $\begin{array}{r}1 \\
9.06 .2 \\
020\end{array}$ & $\begin{array}{r}2 \\
5.06 .2 \\
020\end{array}$ & $\begin{array}{r}2 \\
.07 .20 \\
20\end{array}$ & $\begin{array}{r}7 \\
.07 .20 \\
20\end{array}$ & $\begin{array}{r}13 \\
.07 .202 \\
0\end{array}$ \\
\hline $\begin{array}{r}\text { TTD } \\
\text { in attack }\end{array}$ & $\begin{array}{r}0, \\
753\end{array}$ & $\begin{array}{r}0 \\
, 756\end{array}$ & $\begin{array}{r}0,8 \\
17\end{array}$ & $\begin{array}{r}0, \\
842\end{array}$ & $\begin{array}{r}0, \\
794\end{array}$ & $\begin{array}{r}0, \\
770\end{array}$ & $\begin{array}{r}0 \\
, 844\end{array}$ & $\begin{array}{r}0 \\
836\end{array}$ & $\begin{array}{r}0, \\
831\end{array}$ \\
\hline $\begin{array}{l}\quad \text { TTD } \\
\text { in } \\
\text { defense }\end{array}$ & $\begin{array}{r}0, \\
717\end{array}$ & $\begin{array}{r}0 \\
, 779\end{array}$ & $\begin{array}{l}0,7 \\
73\end{array}$ & $\begin{array}{r}0, \\
662\end{array}$ & $\begin{array}{r}0, \\
691\end{array}$ & $\begin{array}{r}0, \\
749\end{array}$ & $\begin{array}{r}0 \\
, 636\end{array}$ & $\begin{array}{r}0 \\
, 573\end{array}$ & $\begin{array}{r}0 \\
784\end{array}$ \\
\hline $\begin{array}{l}\text { Hous } \\
\text { es } \\
\text { departure }\end{array}$ & $\begin{array}{l}+ \\
-\end{array}$ & $\begin{array}{l}+ \\
-\end{array}$ & $\begin{array}{l}+ \\
-\end{array}$ & $\begin{array}{l}- \\
+\end{array}$ & $\begin{array}{l}+ \\
-\end{array}$ & $\begin{array}{l}- \\
+\end{array}$ & $\begin{array}{l}+ \\
-\end{array}$ & $\begin{array}{l}+ \\
-\end{array}$ & + \\
\hline $\begin{array}{l}\text { Gam } \\
\text { e Score }\end{array}$ & $\begin{array}{l}2 \\
-1\end{array}$ & $-0^{3}$ & $1^{4-}$ & $0^{1-}$ & $0^{5-}$ & $2^{0-}$ & $\begin{array}{r}3 \\
-1\end{array}$ & $-0^{3}$ & $2^{2-}$ \\
\hline
\end{tabular}

\section{REFERENCES}

1. Godik I.A., Sports metrology. 2010.

2. Akramov R.A. Football universities of the XVII World Cup, Tashkent, UzGIFK, 2004.

3. Nurimov A.M. Technique-tactical and physical training of qualified football players. Tutorial. 2001.

4. Zatsiorsky V. M., 1988, "Fundamentals of
Sports Metrology"

5. "Super League of the championship of Uzbekistan 2020: observations, analysis and conclusions." (Talipjanov A.I. in coauthorship)

6. Talipjanov A.I. Yuqori malakali footballolchilar tayorlashning zamonaviy tizimi, toshkent 2012. 